\title{
Correction to: attention effects in working memory that are asymmetric across sensory modalities
}

Yu Li ${ }^{1} \cdot$ Nelson Cowan ${ }^{1}$

Published online: 8 April 2021

(C) The Psychonomic Society, Inc. 2021

\section{Correction to: Mem Cogn.}

https://doi.org/10.3758/s13421-021-01142-9

There was an error in the display of the term "old" in Eq. 1 in this article as originally published, with old appearing between brackets or marks that are not proper quotation marks.

The original article has been corrected.

Publisher's note Springer Nature remains neutral with regard to jurisdictional claims in published maps and institutional affiliations.

The online version of the original article can be found at https://doi.org/ 10.3758/s13421-021-01142-9

\footnotetext{
Nelson Cowan

cowann@missouri.edu

$\mathrm{Yu} \mathrm{Li}$

ylrbc@mail.missouri.edu

1 Department of Psychological Sciences, University of Missouri, McAlester Hall, Columbia, MO 65211, USA
} 